
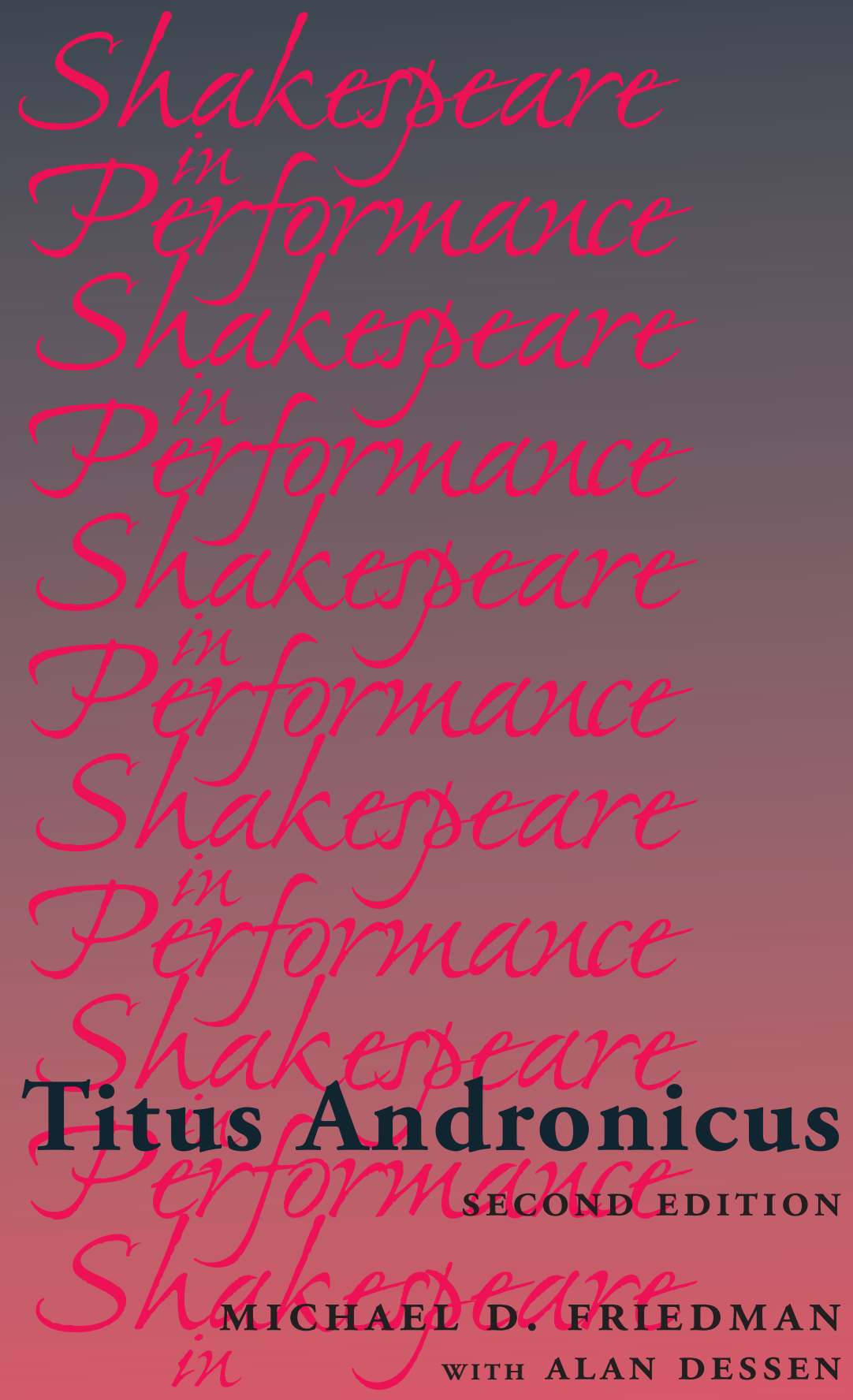


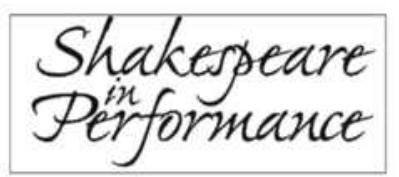

Founding editor: J. R. MULRYNE

General editors:

JAMES C. BULMAN, CAROL CHILLINGTON RUTTER

\section{Titus Andronicus}

\section{MANCHESTER} 1824

Manchester University Press 
Already published in the series

Geraldine Cousin King John

Anthony B. Dawson Hamlet

Mary Judith Dunbar The Winter's Tale

Jay L. Halio A Midsummer Night's Dream (2nd edn)

Stuart Hampton-Reeves and Carol Chillington Rutter The Henry VI plays

Bernice W. Kliman Macbeth (2nd edn)

Alexander Leggatt King Lear (2nd edn)

James Loehlin Henry $V$

Scott McMillin Henry IV, Part One

Lois Potter Othello

Hugh M. Richmond King Henry VIII

Margaret Shewring King Richard II

Virginia Mason Vaughan The Tempest 


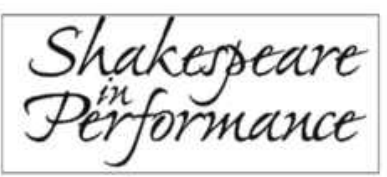

\title{
Titus Andronicus
}

\author{
Michael D. Friedman \\ with Alan Dessen
}

\author{
Second edition
}

Manchester University Press

Manchester and New York

Distributed in the United States exclusively

by Palgrave Macmillan 
Copyright $\odot$ Michael D. Friedman with Alan Dessen 2013

The right of Michael D. Friedman and Alan Dessen to be identified as the authors of this work has been asserted by them in accordance with the Copyright, Designs and Patents Act 1988.

Published by Manchester University Press Oxford Road, Manchester M13 9NR, UK and Room 400, 175 Fifth Avenue, New York, NY 10010, USA www.manchesteruniversitypress.co.uk

Distributed in the United States exclusively by Palgrave Macmillan, 175 Fifth Avenue, New York, NY 10010, USA

Distributed in Canada exclusively by UBC Press, University of British Columbia, 2029 West Mall, Vancouver, BC, Canada V6T 1Z2

British Library Cataloguing-in-Publication Data

A catalogue record for this book is available from the British Library

Library of Congress Cataloging-in-Publication Data applied for

ISBN 9780719082528 hardback

First published 2013

The publisher has no responsibility for the persistence or accuracy of URLs for any external or third-party internet websites referred to in this book, and does not guarantee that any content on such websites is, or will remain, accurate or appropriate.

Typeset by Action Publishing Technology Ltd, Gloucester 